\title{
Moriya_Figure S6
}

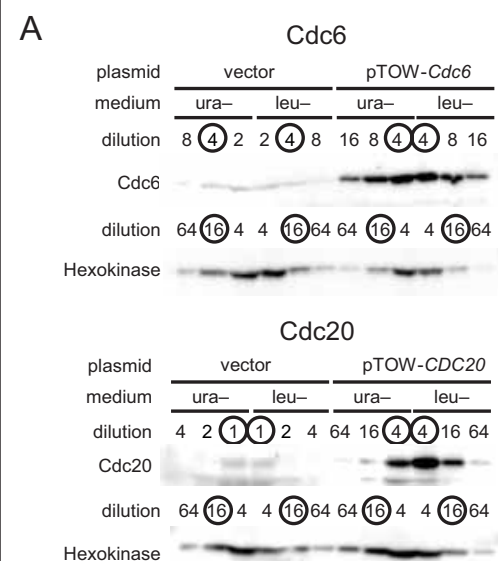

Clb2

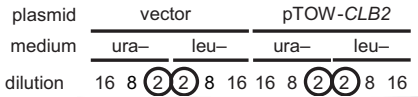

Clb2 - = -

dilution 3216 (4)(4) 16323216 (4)(4) 1632

Hexokinase -

Mad2

plasmid vector

medium $\frac{\text { ura- }}{$\cline { 3 - 3 }}$\frac{\text { leu- }}{164 \text { (2) (2) } 416} \frac{\text { ura- }}{64 \text { (16) } 4} \frac{\text { leu- }}{4 \text { (16) } 64}$

Mad2

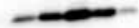

dilution (64) $16 \quad 4 \quad 4 \quad 16$ (64)64) $16 \quad 4 \quad 4 \quad 16$ (64)

Hexokinase - - - - - - -
Cdc14

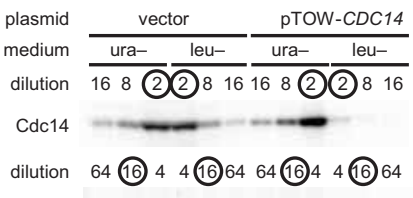

Hexokinase - - - - -

Cdh1

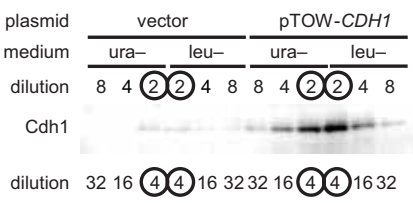

Hexokinase - - - - - -

Clb3

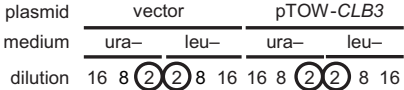

Clb3

dilution 3216 (4)(4) 16323216 (4)(4) 1632

Hexokinase -

Swe1

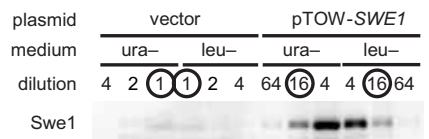

dilution 64 (16) $4 \quad 4$ (16)644 (16)64 64 (16) 4 Hexokinase
Cdc15

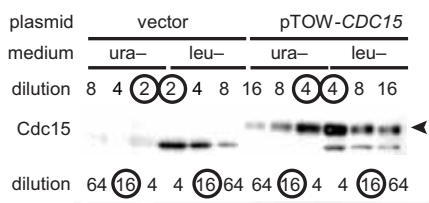

Hexokinase

\section{Clb1}

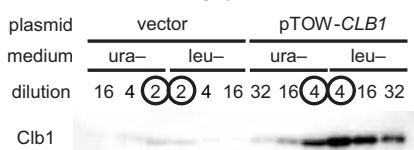

dilution 64 (16) 44 (16)6464 (16) 44 (16) 64

Hexokinase -

\section{Clb5}

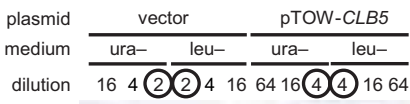

Clb5

dilution 64 (16) 44 (16)6464(16) 44 (16) 64

Hexokinase - - - - -

\section{Swi6}

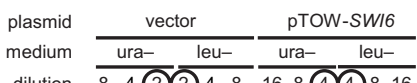

dilution 84 (2)(2) $48 \quad 768$ (4)(4) 816

Swi6 m-m

dilution 32 (16) $4 \quad 4$ (16)3232 (16) $4 \quad 4$ (16)32

Hexokinase _- _ _ _ _ _
B

\section{Cdc28}

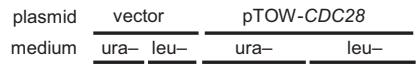

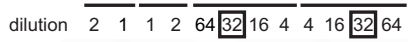

Cdc28

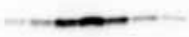

dilution 6416 (4)(4) 16646416 (4)(4) 1664

Hexokinase

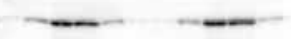

CIn3

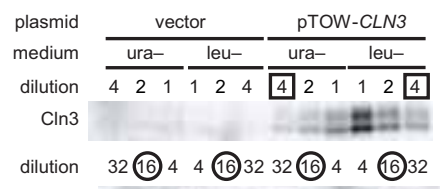

Hexokinase

$$
32 \text { (16) } 4 \quad 4 \text { (16) } 3232 \text { (16) } 4 \quad 4 \text { (16) } 32
$$

\section{Tem1}

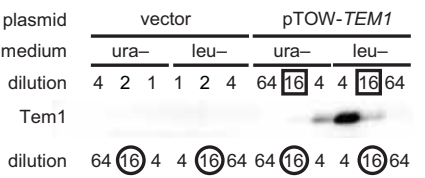

Clb6

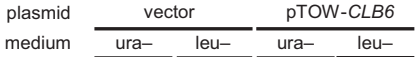

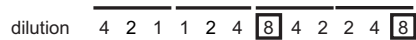

$$
\begin{aligned}
& \text { Clb6 } \\
& \text { dilution } 32 \text { (16) } 4 \quad 4 \text { (16) } 3232 \text { (16) } 4 \quad 4 \text { (16) } 32
\end{aligned}
$$$$
\text { Hexokinase _- _ _ - }
$$

Lte1

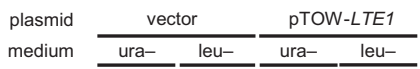

$$
\begin{aligned}
& \text { dilution } \begin{array}{lllllllllllllll}
4 & 2 & 1 & 1 & 2 & 4 & 32 & 8 & 4 & 4 & 8 & 32
\end{array} \\
& \text { Lte1 } \\
& \text { dilution (32) } 16 \quad 4 \quad 4 \quad 16 \text { (32)(32) } 16 \quad 4 \quad 4 \quad 16 \text { (32) }
\end{aligned}
$$

Hexokinase

\section{Cln2}

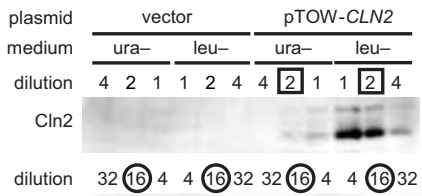

Hexokinase

Net1

$$
\begin{aligned}
& \begin{array}{lll}
\text { plasmid } & \text { vector } & \text { pTOW-NET1 } \\
\cline { 3 - 4 } & \text { ura- leu- } & \text { ura- leu- }
\end{array} \\
& \text { dilution } \begin{array}{lllllllllll}
4 & 2 & 1 & 1 & 2 & 4 & 16 & 8 & 4 & 4 & 8
\end{array} \\
& \text { Net1 } \\
& \text { dilution } 32 \text { (16) } 4 \quad 4 \text { (16) } 3232 \text { (16) } 4 \quad 4 \text { (16) } 32
\end{aligned}
$$

Hexokinase 